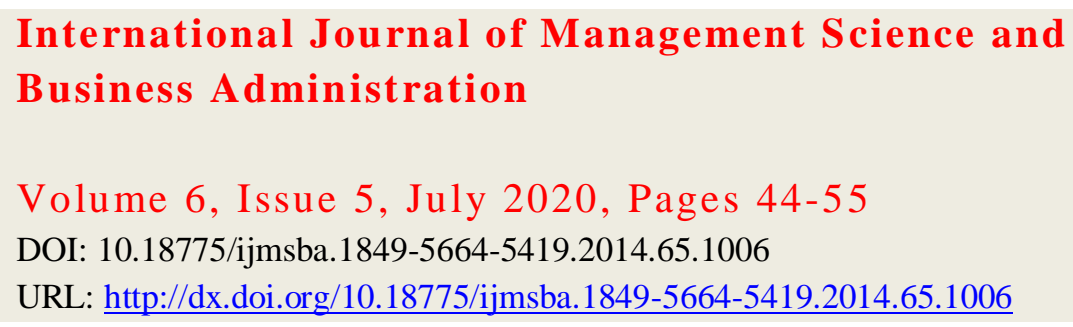

\title{
The Impact of Job Satisfaction on Turnover Rate in the Contact Center Environment in the Jordanian Labor Market
}

\author{
${ }^{1}$ Samira Ismael ${ }^{2}$ Mohammad Shehada \\ ${ }^{1,2}$ Talal Abu-Ghazaleh University College for Innovation, Amman, Jordan
}

\begin{abstract}
The Jordanian economy is declining due to the political and economic conditions in the region, which caused more scarcity of resources and lowering the investment rate. Therefore, the services sector has become more important in the Jordanian labor market and the Contact Center Environment has become even more important. Yet, one of the most brilliant goals for the Contact Center is to lower the turnover rate and deliver the best service to the clients. This paper measured the impact of job satisfaction on turnover rate in the Contact Center Environment. Service providers at inbound call centers answered the questionnaires designed to measure the impact of their job satisfaction with its elements (social satisfaction, salaries, benefits, career growth and safety, psychological and physical environment) on their intent to turnover. 100 questionnaires were distributed randomly in different Contact Centers in the Jordanian labor market. Sixty-eight respondents were received, and the valid ones for analysis were 58. The research identifies a significant impact of Job safety and career growth as major variables that affect the intention and the turnover rate among employees in the Contact Center.
\end{abstract}

Keywords: Job satisfaction, Turnover rate, Jordanian labor market, Job satisfaction impact on turnover rate

\section{Introduction}

Job satisfaction has an important bearing on turnover intent of an employee in the Contact Center. Job satisfaction nowadays is one of the critical issues in the field of Social Sciences. A satisfied employee brings positive affect and desirable work outputs that lead to enhanced efficiency and productivity. In addition to that, it lowers absenteeism and the turnover rate, which will be reflected in reducing hiring costs. People working for several years in the Contact Center Environment and holding many positions there are leaving their jobs, and we always wondered why do they face turnover all the time, and what causes employees to leave their jobs and start looking for another. This research paper would answer that question.

The objectives of this study include:

- Analyzing the satisfaction level of the employees working conditions (psychological and physical)

- Figuring out the satisfaction level of the employees' salaries and benefits.

- Finding out the satisfaction level of employees' Job security and growth.

- Checking out the social satisfaction level of employees towards their job.

- Suggesting some ideas that can improve the satisfaction level of employees.

This research paper will be most beneficial to the Current Managers of the Contact Center: as it will be their guide to know how they can reduce the cost of turnover of their centers, and how to increase the productivity of employees about their satisfaction. It will also be significant for future investors in the Contact Center industry, as it will provide a guideline for them while setting their strategy of building an efficient and effective business that will last.

\section{Definitions of Terms}

\subsection{Job Satisfaction}


Stephen Robbins (2003) defined Job satisfaction as the "difference between the amount of rewards the workers receive and the amount they believe they should receive". Further, he says, "Job satisfaction is an individual general attitude towards his or her job." Kaliski, B.S. (2007) defined it as "a worker's sense of achievement and success on the job. He claims: "It is generally perceived to be directly linked to productivity as well as to personal well-being. Job satisfaction implies doing a job one enjoys, doing it well and being rewarded for one's efforts. Job satisfaction further implies enthusiasm and happiness with one's work. Job satisfaction is the key ingredient that leads to recognition, income, promotion, and the achievement of other goals that lead to a feeling of fulfilment." Job satisfaction can also be defined as "the extent to which a worker is content with the rewards he or she gets out of his or her job, particularly in terms of intrinsic motivation" Statt (2004). "The term job satisfactions refer to the attitude and feelings people have about their work. Positive and favorable attitudes towards the job indicate job satisfaction. Negative and unfavorable attitudes towards the job indicate job dissatisfaction.” Armstrong (2006). Siahaan (2017) found that job satisfaction reduces job stress and improves organizational commitment, while Sayaf (2015) found a positive association between job satisfaction and retention rate.

"Job satisfaction is the collection of feeling and beliefs that people have about their current job. People's levels of degrees of job satisfaction can range from extreme satisfaction to extreme dissatisfaction. In addition to having attitudes about their jobs as a whole. People also can have attitudes about various aspects of their jobs, such as the kind of work they do, their co-workers, supervisors or subordinates, and their pay." George et al. (2008).

Mullins (2005) posits "Job satisfaction is a complex and multifaceted concept which can mean different things to different people. Job satisfaction is usually linked with motivation, but the nature of this relationship is not clear. Satisfaction is not the same as motivation. Job satisfaction is more of an attitude, an internal state. It could, for example, be associated with personal feelings of achievement, either quantitative or qualitative". Job satisfaction represents "a feeling that appears as a result of the perception that the job enables the material and psychological needs" Aziri (2008). Job satisfaction may reflect the joy of having an occupation (Tchinda and Bing, 2017).

\subsection{Contact Centre Environment}

According to Steve Taylor and Larry Hettick, "The interactions between callers and customer service representatives are supported by the collective system of computers, telephones and the Internet. The shift from CTI to contact centre telephony is marked by the sheer change in the customer's behavior when it comes to communication. Means customers are no longer confined only to voice-based communication, i.e. phone to connect with their customer service departments. Also, they are making use of email, SMS, chat, social media, and other virtual contact channels. This is also the reason for the shift in nomenclature from "call centres" to "contact canters", "contact" being a wider term than "call". Respecting the trend, contact centre owners need to adopt unified communication or a multi-channel approach to let customers get in touch with them via their preferred communication mediums, either voice or non-voice (data). Cloud-based phone system is a further advancement in the direction as it allows operators to access all the features and benefits of call centre telephony over the Web against an affordable \& flexible pay-as-you-go subscription model”. (WIKIPEDIA)

"The main difference between a call centre and a contact centre is that while a call centre is focusing on incoming and outgoing voice calls, it can manage customers with both voice calls and data applications like e-mail, Web-based chat/instant messaging, and in some cases will include the capability to share Web pages sent to and from the customer. The fully functional contact centre takes advantage of customer needs for text and visual communications in addition to phone calls; typically, a contact centre also uses a "blended agent" who can manage multiple forms of voice and datacentric customer communications". (Network World)

\subsection{Turnover}

March and Simon argue, "Individual's turnover when they perceive that their contributions to an organization exceed the inducements they receive from that organization. This inducement-contribution balance is broadly influenced by two factors: a) one's desire to move, which is generally a function of one's satisfaction with the work environment, and b) one's ease of movement, which is influenced by macro- and individual-level factors that determine employability." (March and Simon).

Employee turnover is more and more challenging for HR departments, with job satisfaction notably influencing the turnover rate. Tshivhase and Vilakazi (2018) examined the relationship between company employees and five 
determinants of employee turnover. Previous studies also found a negative relationship between job satisfaction and turnover intention (Stater and Stater, 2019; Chen and Wang, 2019; Asim and Asim, 2019). Chen et al. (2019) found that providing more opportunities to improve job satisfaction could help in reducing employee turnover rate. Met Expectations Theory for Porter and Steers says, "Building on the organization equilibrium theory of turnover, they posit that met expectations are a key determinant in turnover decisions. The concept of met expectations is defined as "the discrepancy between what a person encounters on this job in the way of positive and negative experiences and what he expected to encounter" The set of expectations a person has of an employer may include rewards, advancement, and relations with peers and supervisors. Specifically, Porter and Steers argue that an individual is likely to turnover because of dissatisfaction arising from his or her employer failing to meet a set of expectations.” Porter and Steers (1973).

\subsection{Research Hypothesis}

- Ho: Job satisfaction has no impact on the turnover rate in the Contact Center Environment in Amman, Jordan, at $(0=0.5)$.

- Ho1: Social Satisfaction has no impact on the turnover rate in the Contact Center Environment in Amman, Jordan, at $(0=0.5)$.

- Ho2: Salaries and Benefits have no impact on the turnover rate in the Contact Center Environment in Amman, Jordan, at $(0=0.5)$.

- Ho3: The Physical environment has no impact on the turnover rate in the Contact Center Environment in Amman, Jordan, at $(0=0.5)$.

- Ho4: The Psychological environment has no impact on the turnover rate in the Contact Center Environment in Amman, Jordan, at $(0=0.5)$.

- Ho5: Career Growth and safety have no impact on the turnover rate in the Contact Center Environment in Amman, Jordan, at $(0=0.5)$.

- Ho6: Job satisfaction with its elements (social satisfaction, salaries and benefits, physical environment, career growth, and safety) makes no difference on turnover when it comes to the demographical and functional variables (Gender, Age, years of experience and Educational Qualifications) in the Contact Center Environment in Amman, Jordan, at $(0=0.5)$.

Study Model

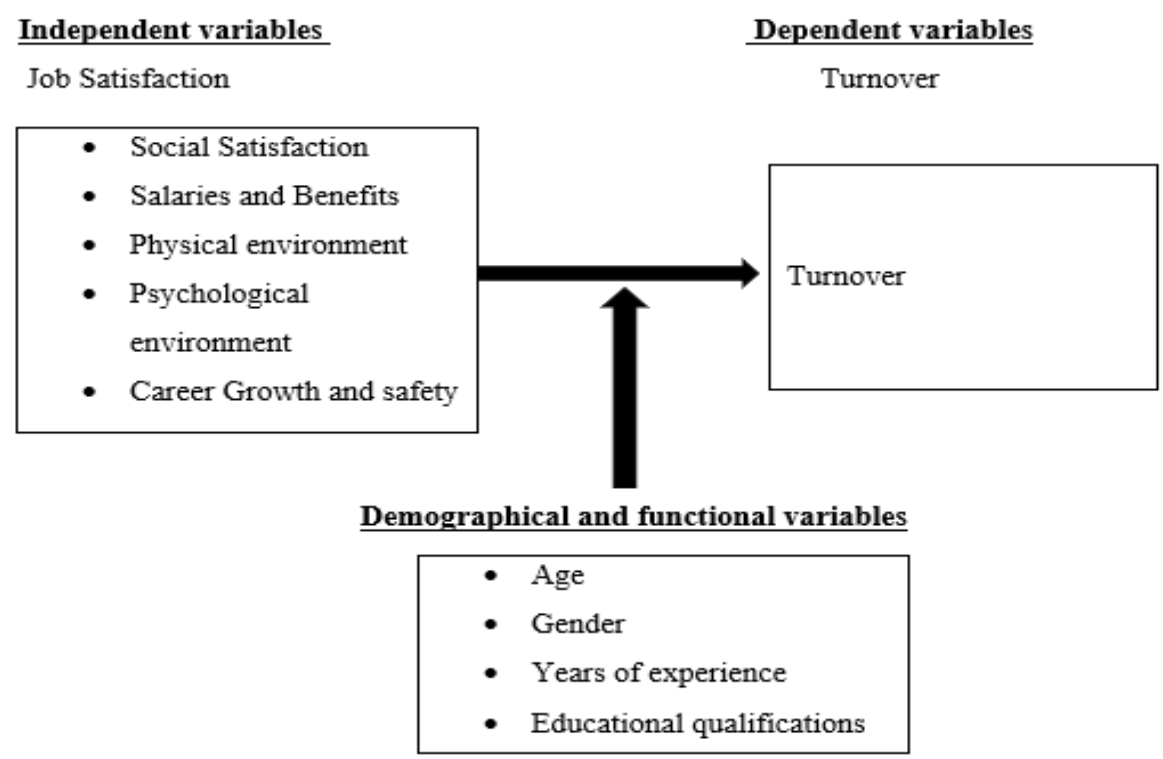

Figure 1: Study Model

\section{Research Methodology}

\subsection{Nature of Research}


This research is considered descriptive and analytical. It describes the job satisfaction phenomenon and the variables that measure satisfaction. Also, it sheds light on the turnover element. It is also analytical because we use statistical analysis by using Statistical Package for Social Sciences (SPSS) for explaining the paragraphs of the questionnaire.

Sources of Information:

The current study used two sources to get data, secondary and primary sources. In the secondary source, the literature data was collected from various available sources that include published articles, books, previous studies and website materials in order to form the theoretical framework of the study.

The primary source was gathered from a questionnaire that was formed and used to reflect the study objectives and needs. Study Population and Unit of Analysis:

The population of the study covers all the employees of the Contact Centre in the Jordanian labor market, yet defining the whole number of those employees was hard due to the privacy and transparency taken by these centres. These contact centres do not give exact numbers because they do not want to expose themselves to the taxation department in Jordan. 100 employees were randomly selected for the purpose of this study. 75 questionnaires were received, but 58 were valid.

\subsection{Statistical Analysis}

Reliability and Validity

Table 1: Reliably Statistics (Cronbach alpha)

\begin{tabular}{|l|l|}
\hline Cronbach's Alpha & N of Items \\
\hline .749 & 58 \\
\hline
\end{tabular}

The reliability analysis shows that the value is (0.749), which is $(>0.7)$. This indicates a positive scale reliability.

\subsection{Research Scope}

This research discussed job satisfaction as a major determinant of an employee intention to turnover, it covered the Jordanian labor market only and it covered the non-managerial level (Agent level).

\subsection{Statistical Analysis}

Demographics Analysis

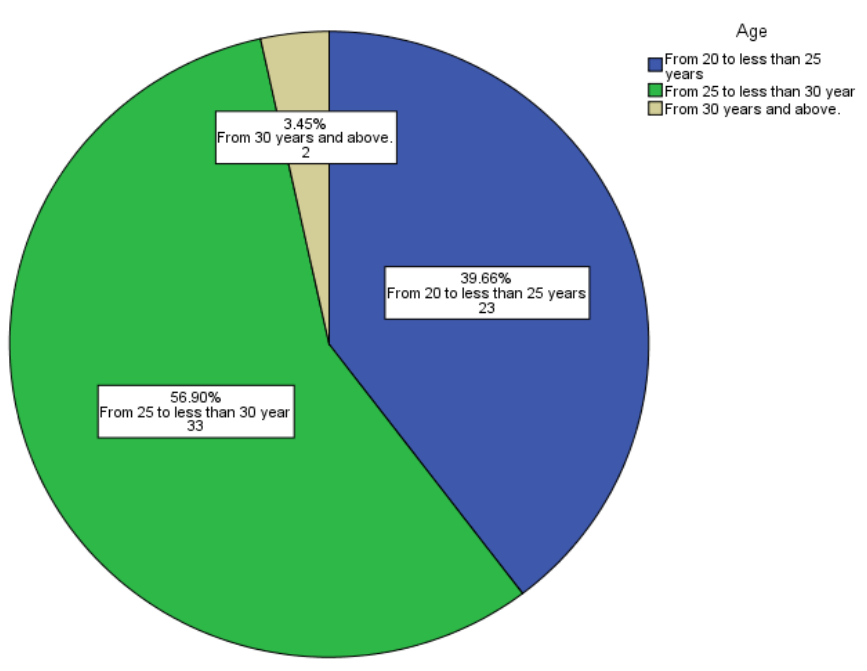

Figure 2: Distribution of Respondents according to age 
Samira Ismael, Mohammad Shehada

The Impact of Job Satisfaction on Turnover Rate in the Contact Center Environment in the Jordanian Labor Market

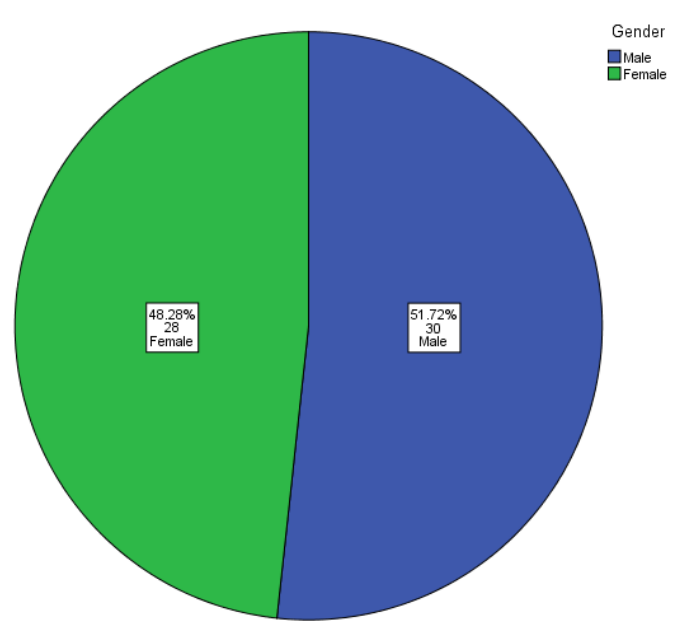

Figure 3: Distribution of respondents according to gender

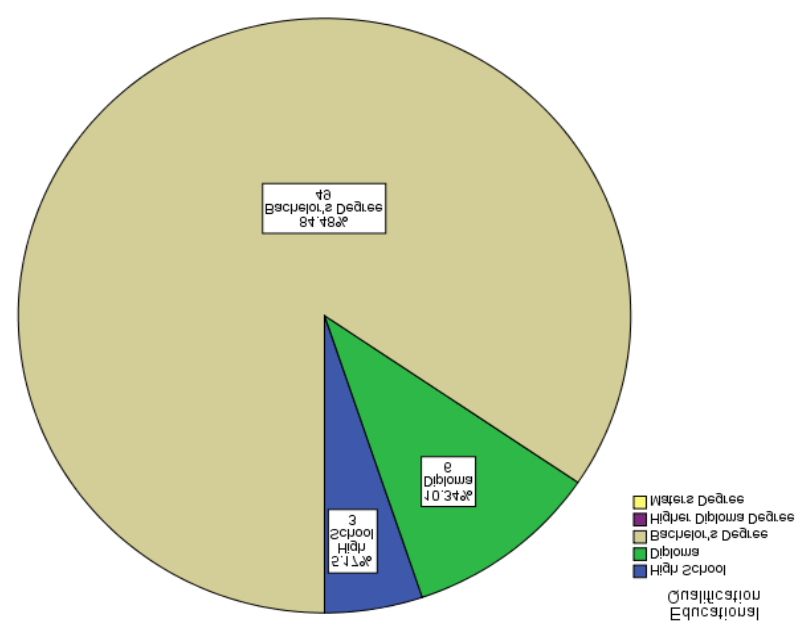

Figure 4: Distribution of respondents according to level of education

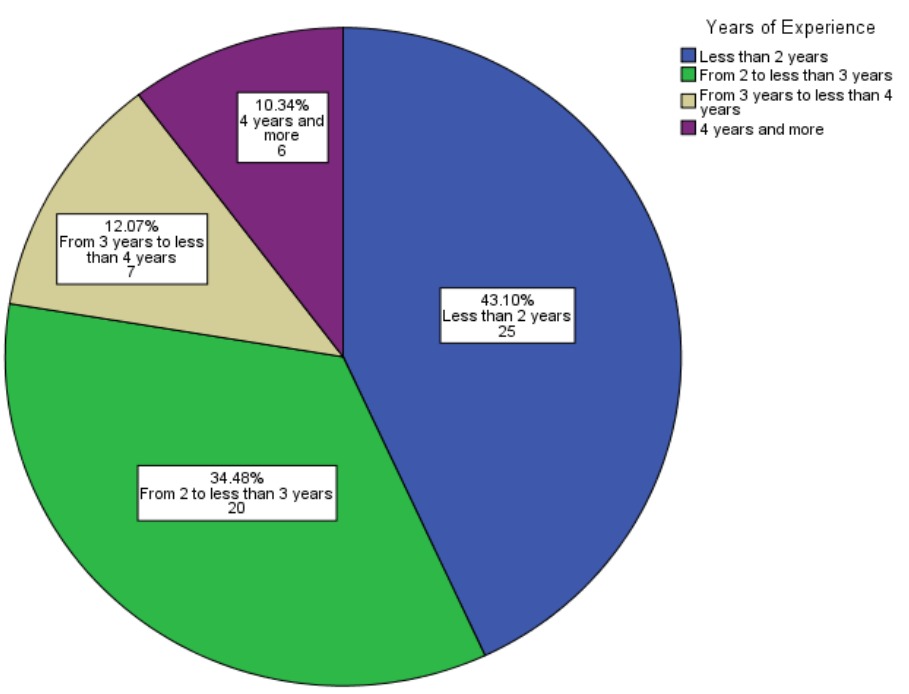

Figure 5: Distribution of respondents according to years of experience 
Samira Ismael, Mohammad Shehada

The Impact of Job Satisfaction on Turnover Rate in the Contact Center Environment in the Jordanian Labor Market

\section{Data Analysis}

Table 2: Levels of variables

\begin{tabular}{|l|l|l|l|l|l|}
\hline Variable & Mean & Mode & SD & Skewness & N \\
\hline Social Satisfaction & 2.69 & 2 & .664 & .298 & 58 \\
\hline Salaries Benefits & 2.76 & 3 & .632 & .048 & 58 \\
\hline Physical Environment & 2.44 & 2 & .736 & .194 & 58 \\
\hline Career Growth and Safety & 2.62 & 3 & .549 & .088 & 58 \\
\hline Psychological Environment & 2.66 & 3 & .708 & .781 & 58 \\
\hline Turnover & 2.59 & 2 & .663 & .139 & \\
\hline
\end{tabular}

\subsection{Research Hypotheses}

Ho1: job satisfaction has no impact on the turnover rate in Contact Centre Environment.

A simple regression analysis was conducted to test the main hypothesis that "job satisfaction has no impact on the turnover rate in the Contact Centre Environment"

Table 3: Job satisfaction as predictor on turnover rate

\begin{tabular}{|c|c|c|c|c|c|c|c|c|c|}
\hline Model & $\mathbf{R}$ & $\mathbf{R}^{2}$ & $\operatorname{Adj} R^{2}$ & $\mathbf{F}$ & Sig & $\beta$ & $\begin{array}{l}\text { Std. } \\
\text { Error }\end{array}$ & $\mathbf{t}$ & Sig. \\
\hline (Constant) & \multirow{2}{*}{.190} & \multirow{2}{*}{.026} & \multirow{2}{*}{.019} & \multirow{2}{*}{2.098} & \multirow{2}{*}{.153} & 1.718 & .605 & 2.839 & .006 \\
\hline Job Satisfaction & & & & & & .329 & .227 & 1.449 & .153 \\
\hline
\end{tabular}

From the above table, and in general, the model is not significant $(\mathrm{F}=2.098$, $\mathrm{p}$-value $=0.153<0.05)$.

- Job satisfaction has no significant impact on the turnover rate $(\mathrm{t}=1.197, \mathrm{p}$-value $=0.237>0.05)$.

Ho2: Social Satisfaction has no impact on the turnover rate in Contact Centre Environment A simple regression was conducted to test the hypothesis that "Social satisfaction has no impact on the turnover rate in Contact Centre Environment."

Table 4: Social satisfaction as a predictor of turnover rate

\begin{tabular}{|c|c|c|c|c|c|c|c|c|c|}
\hline Model & $\mathbf{R}$ & $\mathbf{R}^{2}$ & $\operatorname{Adj} R^{2}$ & $\mathbf{F}$ & Sig & $\boldsymbol{\beta}$ & Std. Error & $\mathbf{t}$ & Sig. \\
\hline (Constant) & \multirow{2}{*}{.258} & \multirow{2}{*}{.067} & \multirow{2}{*}{.050} & \multirow{2}{*}{4.006} & \multirow{2}{*}{.050} & 1.893 & .357 & 5.304 & .000 \\
\hline Social satisfaction & & & & & & .258 & .129 & 2.001 & .050 \\
\hline
\end{tabular}

From the above table:

- The model is not significant $(\mathrm{F}=4.006$, $\mathrm{p}$-value $=0.050=0.05)$ with $\mathrm{R}=0.258$ and $\mathrm{R} 2=0.086$.

- Social satisfaction has no a significant impact on turnover rate $(\mathrm{t}=2.001, \mathrm{p}$-value $=0.050=0.05)$.

Ho3: Salaries and Benefits has no impact on the turnover rate in Contact Centre Environment

Table 5: Salaries and benefits as a predictor of turnover rate

\begin{tabular}{|c|c|c|c|c|c|c|c|c|c|}
\hline Model & $\mathbf{R}$ & $\mathbf{R}^{2}$ & $\operatorname{Adj} R^{2}$ & $\mathbf{F}$ & Sig & $\beta$ & $\begin{array}{l}\text { Std. } \\
\text { Error }\end{array}$ & $\mathbf{t}$ & Sig. \\
\hline (Constant) & & & & & & 2.814 & .396 & 7.110 & .000 \\
\hline $\begin{array}{l}\text { Salaries and } \\
\text { Benefits }\end{array}$ & .019 & .000 & -.012 & .047 & $.5 J 0$ & -.082 & .140 & -.589 & .558 \\
\hline
\end{tabular}


From the above table:

The model is not significant $(\mathrm{F}=.347$, $\mathrm{p}$-value $=0.558>0.05)$ with $\mathrm{R}=0.079$ and $\mathrm{R} 2=0.006$.

Salaries and Benefits has no a significant Impact on the turnover rate $(\mathrm{t}=2.001, \mathrm{p}$-value $=0.050>0.05)$.

Ho4: Physical environment has no impact on the turnover rate in Contact Centre Environment.

Table 6: Physical environment as a predictor of turnover rate

\begin{tabular}{|c|c|c|c|c|c|c|c|c|c|}
\hline Model & $\mathbf{R}$ & $\mathbf{R}^{2}$ & $\operatorname{Adj} R^{2}$ & $\mathbf{F}$ & Sig & $\boldsymbol{\beta}$ & $\begin{array}{l}\text { Std. } \\
\text { Error }\end{array}$ & $\mathbf{t}$ & Sig. \\
\hline (Constant) & \multirow{2}{*}{.106} & \multirow{2}{*}{.001} & \multirow{2}{*}{-.006} & \multirow{2}{*}{.635} & \multirow{2}{*}{.429} & 2.819 & .305 & 9.251 & .000 \\
\hline Physical environment & & & & & & -.095 & .120 & -.797 & .429 \\
\hline
\end{tabular}

From the above table:

- The model is not significant $(\mathrm{F}=.635$, $\mathrm{p}$-value $=0.429>0.05)$ with $\mathrm{R}=0.106$ and $\mathrm{R} 2=0.001$.

- Physical environment has no a significant effect on turnover rate $(\mathrm{t}=-0.797, \mathrm{p}$-value $=0.429>0.05)$.

Ho5: Psychological environment has no impact on the turnover rate in Contact Centre Environment.

Table 7: Psychological environment as a predictor of turnover rate

\begin{tabular}{|c|c|c|c|c|c|c|c|c|c|}
\hline Model & $\mathbf{R}$ & $\mathbf{R}^{2}$ & $\operatorname{Adj} R^{2}$ & $\mathbf{F}$ & Sig & $\beta$ & $\begin{array}{l}\text { Std. } \\
\text { Error }\end{array}$ & $\mathbf{t}$ & Sig. \\
\hline (Constant) & \multirow[b]{2}{*}{.122} & \multirow[b]{2}{*}{.015} & \multirow[b]{2}{*}{-.003} & \multirow[b]{2}{*}{.846} & \multirow[b]{2}{*}{.362} & 2.282 & .342 & 6.681 & .000 \\
\hline $\begin{array}{l}\text { Psychological } \\
\text { environment }\end{array}$ & & & & & & .114 & .124 & .920 & .362 \\
\hline
\end{tabular}

From the above table:

- The model is not significant $(\mathrm{F}=.846$, $\mathrm{p}$-value $=0.362>0.05)$ with $\mathrm{R}=0.122$ and $\mathrm{R} 2=0.015$.

- Psychological environment has no a significant effect on turnover rate $(\mathrm{t}=-0.920$, $\mathrm{p}$-value=.362>0.05).

Ho6: Career Growth and safety has no impact on the turnover rate in contact center environment.

Table 8: Career Growth and safety as a predictor of turnover rate

\begin{tabular}{|c|c|c|c|c|c|c|c|c|c|}
\hline Model & $\mathbf{R}$ & $\mathbf{R}^{2}$ & $\operatorname{Adj} R^{2}$ & $\mathbf{F}$ & Sig & $\boldsymbol{\beta}$ & $\begin{array}{l}\text { Std. } \\
\text { Error }\end{array}$ & $\mathbf{t}$ & Sig. \\
\hline (Constant) & \multirow[b]{2}{*}{.425} & \multirow[b]{2}{*}{.181} & \multirow[b]{2}{*}{.166} & \multirow[b]{2}{*}{12.343} & \multirow[b]{2}{*}{.001} & 1.240 & .391 & 3.168 & .002 \\
\hline $\begin{array}{l}\text { Career Growth and } \\
\text { safety }\end{array}$ & & & & & & .514 & .146 & 3.513 & .001 \\
\hline
\end{tabular}

From the above table:

- The model is significant $(\mathrm{F}=.12 .343$, $\mathrm{p}$-value $=0.001>0.05)$ with $\mathrm{R}=0.425$ and $\mathrm{R} 2=0.181$.

- Career growth and safety has a significant impact on turnover rate $(\mathrm{t}=-3.513, \mathrm{p}$-value $=.001<0.05)$.

Ho7: There are no difference between social satisfaction, salaries and benefits, physical environment, career growth and safety when it comes to the demographical and functional variables (Gender, Age, Educational Qualification, and the years of experience)

i. T-tests: (Gender).

ii. ANAOVA: (Age, Level of Education, and years of experience).

\subsection{Gender}

Two independent samples were used to test that there are no significant differences in the levels of social satisfaction, salaries and benefits, physical environment, career growth and safety, and psychological environment that can be attribute to gender: 
Samira Ismael, Mohammad Shehada

The Impact of Job Satisfaction on Turnover Rate in the Contact Center Environment in the Jordanian Labor Market

Table 9: T-test / Gender attribution to variables

\begin{tabular}{|c|c|c|c|c|c|}
\hline Variable & $\mathbf{t}$ & df & $\begin{array}{l}\text { Sig. } \\
\text { tailed) }\end{array}$ & $\begin{array}{l}\text { Mean } \\
\text { Difference }\end{array}$ & $\begin{array}{l}\text { Std. Error } \\
\text { Difference }\end{array}$ \\
\hline Social Satisfaction & -.074 & 56 & 941 & -.013 & 176 \\
\hline Salaries Benefits & -.160 & 56 & .874 & -.027 & 168 \\
\hline Physical Environment & -1.701 & 56 & .095 & -.324 & 190 \\
\hline Career_Growth_Safety & -1.766 & 56 & .083 & -.250 & .142 \\
\hline Psychological Environment & -.939 & 56 & .352 & -.175 & 186 \\
\hline Turnover & -1.331 & 56 & 189 & -.230 & .173 \\
\hline
\end{tabular}

From the above table, there are no differences in the levels of social satisfaction, salaries and benefits, physical environment, career growth and safety, and psychological environment that can be attribute to gender.

\subsection{Age}

Analysis of variance was conducted to test that there are no significant differences in the levels of the levels of social satisfaction, salaries and benefits, physical environment, career growth and safety, and psychological environment that can be attribute to age.

Table 10: ANOVA / Age attribution to variables

\begin{tabular}{|c|c|c|c|c|c|c|}
\hline Variable & source of variation & Sum of Squares & df & $\begin{array}{l}\text { Mean } \\
\text { Square }\end{array}$ & $\mathbf{F}$ & Sig. \\
\hline \multirow{3}{*}{$\begin{array}{l}\text { Social } \\
\text { satisfaction }\end{array}$} & Between Groups & 1.486 & 2 & .743 & 1.725 & .188 \\
\hline & Within Groups & 23.678 & 55 & .431 & & \\
\hline & Total & 25.164 & 57 & & & \\
\hline \multirow{3}{*}{$\begin{array}{l}\text { Salaries and } \\
\text { benefits }\end{array}$} & Between Groups & .561 & 2 & .281 & .694 & .504 \\
\hline & Within Groups & 22.242 & 55 & .404 & & \\
\hline & Total & 22.803 & 57 & & & \\
\hline \multirow{3}{*}{$\begin{array}{l}\text { Physical } \\
\text { environment }\end{array}$} & Between Groups & 2.570 & 2 & 1.285 & 2.494 & .092 \\
\hline & Within Groups & 28.343 & 55 & .515 & & \\
\hline & Total & 30.914 & 57 & & & \\
\hline \multirow{3}{*}{$\begin{array}{l}\text { Career growth } \\
\text { and safety }\end{array}$} & Between Groups & .444 & 2 & .222 & .731 & 486 \\
\hline & Within Groups & 16.711 & 55 & .304 & & \\
\hline & Total & 17.155 & 57 & & & \\
\hline
\end{tabular}


Samira Ismael, Mohammad Shehada

The Impact of Job Satisfaction on Turnover Rate in the Contact Center Environment in the Jordanian Labor Market

\begin{tabular}{|l|l|l|l|l|l|l|}
\multirow{4}{*}{$\begin{array}{l}\text { Psychological } \\
\text { environment }\end{array}$} & Between Groups & .981 & 2 & .490 & .977 & .383 \\
\cline { 2 - 7 } & Within Groups & 27.607 & 55 & .502 & & \\
\cline { 2 - 7 } & Total & 28.587 & 57 & & & \\
\hline \multirow{4}{*}{ Turnover } & Between Groups & .234 & 2 & .117 & .259 & .773 \\
\cline { 2 - 7 } & Within Groups & 24.835 & 55 & .452 & & \\
\cline { 2 - 7 } & Total & 25.069 & 57 & & & \\
\hline
\end{tabular}

From the above table, there are no significant differences in the levels of social satisfaction, salaries and benefits, physical environment, career growth and safety, and psychological environment that can be attributed to age.

\subsection{Level of Education}

Analysis of variance was conducted to test that there are no significant differences in the levels of social satisfaction, salaries and benefits, physical environment, career growth and safety, and psychological environment that can be attribute to Level of education

Table 11: ANOVA / Level of education attribution to variables

\begin{tabular}{|c|c|c|c|c|c|c|}
\hline Variable & source of variation & Sum of Squares & df & $\begin{array}{l}\text { Mean } \\
\text { Square }\end{array}$ & $\mathbf{F}$ & Sig. \\
\hline \multirow{3}{*}{$\begin{array}{l}\text { Social } \\
\text { satisfaction }\end{array}$} & Between Groups & .157 & 2 & .078 & .173 & .842 \\
\hline & Within Groups & 25.007 & 55 & .455 & & \\
\hline & Total & 25.164 & 57 & & & \\
\hline \multirow{3}{*}{$\begin{array}{l}\text { Salaries and } \\
\text { benefits }\end{array}$} & Between Groups & 1.018 & 2 & .509 & 1.285 & .285 \\
\hline & Within Groups & 21.785 & 55 & .396 & & \\
\hline & Total & 22.803 & 57 & & & \\
\hline \multirow{3}{*}{$\begin{array}{l}\text { Physical } \\
\text { environment }\end{array}$} & Between Groups & 4.964 & 2 & 2.482 & 5.260 & .008 \\
\hline & Within Groups & 25.950 & 55 & .472 & & \\
\hline & Total & 30.914 & 57 & & & \\
\hline \multirow{3}{*}{$\begin{array}{l}\text { Career growth } \\
\text { and safety }\end{array}$} & Between Groups & .059 & 2 & .030 & .095 & .909 \\
\hline & Within Groups & 17.096 & 55 & .311 & & \\
\hline & Total & 17.155 & 57 & & & \\
\hline \multirow{3}{*}{$\begin{array}{l}\text { Psychological } \\
\text { environment }\end{array}$} & Between Groups & 1.421 & 2 & .711 & 1.439 & .246 \\
\hline & Within Groups & 27.166 & 55 & .494 & & \\
\hline & Total & 28.587 & 57 & & & \\
\hline \multirow{3}{*}{ Turnover } & Between Groups & .201 & 2 & .100 & .222 & .802 \\
\hline & Within Groups & 24.868 & 55 & .452 & & \\
\hline & Total & 25.069 & 57 & & & \\
\hline
\end{tabular}


From the above table, there are significant differences in the career growth and safety that can be attributed to levels of education. LSD test showed that Bachelor and diploma groups tends to have lower scores compared to high school group. (p-value 0.049>0.05).

\subsection{Years of Experience}

Analysis of variance was conducted to test that there are no significant differences in the levels of social satisfaction, salaries and benefits, physical environment, career growth and safety, and psychological environment that can be attribute to years of experience

Table 12: ANOVA / Years of experience attribution to variables

\begin{tabular}{|c|c|c|c|c|c|c|}
\hline Variable & source of variation & Sum of Squares & df & $\begin{array}{l}\text { Mean } \\
\text { Square }\end{array}$ & $\mathbf{F}$ & Sig. \\
\hline \multirow{3}{*}{$\begin{array}{l}\text { Social } \\
\text { satisfaction }\end{array}$} & Between Groups & 1.279 & 3 & .426 & .963 & .417 \\
\hline & Within Groups & 23.885 & 54 & .442 & & \\
\hline & Total & 25.164 & 57 & & & \\
\hline \multirow{3}{*}{$\begin{array}{l}\text { Salaries and } \\
\text { benefits }\end{array}$} & Between Groups & .039 & 3 & .013 & .031 & .993 \\
\hline & Within Groups & 22.764 & 54 & .422 & & \\
\hline & Total & 22.803 & 57 & & & \\
\hline \multirow{3}{*}{$\begin{array}{l}\text { Physical } \\
\text { environment }\end{array}$} & Between Groups & .687 & 3 & .229 & .409 & .747 \\
\hline & Within Groups & 30.227 & 54 & .560 & & \\
\hline & Total & 30.914 & 57 & & & \\
\hline \multirow{3}{*}{$\begin{array}{l}\text { Career growth } \\
\text { and safety }\end{array}$} & Between Groups & 1.126 & 3 & .375 & 1.264 & .296 \\
\hline & Within Groups & 16.029 & 54 & .297 & & \\
\hline & Total & 17.155 & 57 & & & \\
\hline \multirow{3}{*}{$\begin{array}{l}\text { Psychological } \\
\text { environment }\end{array}$} & Between Groups & .490 & 3 & .163 & .314 & .815 \\
\hline & Within Groups & 28.097 & 54 & .520 & & \\
\hline & Total & 28.587 & 57 & & & \\
\hline \multirow{3}{*}{ Turnover } & Between Groups & 1.362 & 3 & .454 & 1.034 & .385 \\
\hline & Within Groups & 23.707 & 54 & .439 & & \\
\hline & Total & 25.069 & 57 & & & \\
\hline
\end{tabular}

From the above table, there are no significant differences in the levels of social satisfaction, salaries and benefits, physical environment, career growth and safety, and psychological environment that can be attributed to years of experience.

\section{Conclusion}

The results of our research identify four variables that might affect the turnover rate in the contact center. First, social satisfaction regarding the job has no significant impact on turnover intentions as well as the physical environment, psychological environment and job safety and career growth.

Yet, it also identifies when there are opportunities for better and higher salaries and benefits; there is an impact on turnover intentions. In other words, even if the employees are satisfied with the physical environment, psychological environment, and career safety and growth, employees of the Contact Center are less likely to consider leaving their company if they have better salaries and better benefits than the other companies or industries.

\subsection{Recommendations and Future Research}

Improving satisfaction plays an important role in retaining employees when the employee perceives better opportunities, 
therefor we recommend the below ideas in order to enhance satisfaction of employees and to find better ways to retain them:

- Managing external employment opportunities or perceptions of organization support efforts should be a core focus in organizations where employees are expected to contribute more to be retained actively.

- Finding a retention plan that considers employees previous and current experience within the company.

- Studying the market, salaries in particular, to benefit employees and implement a better salary scale and benefits within the company's budget.

The study was conducted only on the Contact Center Environment at Jordanian labor market. It would be recommended that future researches be conducted on a larger sample to get results that are more precise. The Contact Center can target its employees on all the applications used in the study. A replication of this study on another sample would benefit the research.

\section{References}

- Alexander, M., MacLaren, A., O’Gorman, K., \& Taheri, B. (2012), “He just didn’t seem to understand the banter: Bullying or simply establishing social cohesion", Tourism Management, 33(5), 1245-1255. Crossref

- Alam, A., \& Asim, M. (2019), "Relationship between job satisfaction and turnover intention", International Journal of Human Resources Studies. ISSN, 2162-3058. Crossref

- Baum, T., Kralj, A., Robinson, R. N., \& Solnet, D. J. (2016), "Tourism workforce research: A review, taxonomy and agenda", Annals of Tourism Research, 60, 1-22. Crossref

- Bufquin, D., DiPietro, R., Orlowski, M., \& Partlow, C. (2017), “The influence of restaurant co-workers' perceived warmth and competence on employees' turnover intentions: The mediating role of job attitudes”, International Journal of Hospitality Management, 60, 13-22. Crossref

- Chen, X., Ran, L., Zhang, Y., Yang, J., Yao, H., Zhu, S., \& Tan, X. (2019), "Moderating role of job satisfaction on turnover intention and burnout among workers in primary care institutions", A cross-sectional study. BMC public health, 19 (1), 1526. Crossref

- Cohen, G., Blake, R. S., \& Goodman, D. (2016), "Does turnover intention matter? Evaluating the usefulness of turnover intention rate as a predictor of actual turnover rate", Review of Public Personnel Administration, 36(3), 240 263. Crossref

- Dhar, R. L. (2015), "Service quality and the training of employees: The mediating role of organizational commitment", Tourism Management, 46, 419-430. Crossref

- Díaz, E., Martín-Consuegra, D., \& Esteban, Á. (2015), "Perceptions of service cannibalization: The moderating effect of the type of travel agency", Tourism Management, 48, 329-342. Crossref

- Elbaz, A. M., \& Haddoud, M. Y. (2017), "The role of wisdom leadership in increasing job performance: Evidence from the Egyptian tourism sector", Tourism Management, 63, 66-76. Crossref

- Gao, B., Li, X., Liu, S., \& Fang, D. (2018), "How power distance affects online hotel ratings: The positive moderating roles of hotel chain and reviewers' travel experience", Tourism Management, 65, 176-186. Crossref

- George, J.M., et.al. (2008), “Understanding and Managing Organizational behavior”, Pearson/Prentice Hall, New Jersey.

- Hom, P. W., Lee, T. W., Shaw, J. D., \& Hausknecht, J. P. (2017), “One hundred years of employee turnover theory and research", Journal of Applied Psychology, 102(3), 530. Crossref

- Huang, M., Li, P., Meschke, F., \& Guthrie, J. P. (2015), "Family firms, employee satisfaction, and corporate performance", Journal of Corporate Finance, 34, 108-127. Crossref

- Huang, Y.-T., \& Rundle-Thiele, S. (2014), "The moderating effect of cultural congruence on the internal marketing practice and employee satisfaction relationship: An empirical examination of Australian and Taiwanese born tourism employees", Tourism Management, 42, 196-206. Crossref

- Kara Kim, H., Im, J., \& Qu, H. (2018), "Exploring antecedents and consequences of job crafting”, International Journal of Hospitality Management, 75, 18-26. Crossref

- Korfiatis, N., Stamolampros, P., Kourouthanassis, P., \& Sagiadinos, V. (2019), "Measuring service quality from unstructured data: A topic modeling application on airline passengers' online reviews", Expert Systems with Applications, 116, 472-486. Crossref 
- Ladkin, A., \& Buhalis, D. (2016), “Online and social media recruitment: Hospitality employer and prospective employee considerations", International Journal of Contemporary Hospitality Management, 28 (2), $327-345$. Crossref

- Lee, C.-K., Song, H.-J., Lee, H.-M., Lee, S., \& Bernhard, B. J. (2013), “The impact of CSR on casino employees’ organizational trust, job satisfaction, and customer orientation: An empirical examination of responsible gambling strategies", International Journal of Hospitality Management, 33, 406-415. Crossref

- Lee, M., \& Mimno, D. (2014). Low-dimensional Embedding for Interpretable Anchor-based Topic Inference. In proceedings of the 2014 Conference on Empirical Methods in Natural Language Processing (EMNLP) (pp. 13191328). Doha, Qatar: Association for Computational Linguistics. Crossref

- Lee, T. W., Hom, P. W., Eberly, M. B., Li, J. (Jason), \& Mitchell, T. R. (2017), “On the next decade of research in voluntary employee turnover", Academy of Management Perspectives, 31(3), 201-221. Crossref

- Lu, A. C. C., \& Gursoy, D. (2016), "Impact of job burnout on satisfaction and turnover intention: Do generational differences matter?”, Journal of Hospitality \& Tourism Research, 40(2), 210-235. Crossref

- McPhail, R., Patiar, A., Herington, C., Creed, P., \& Davidson, M. (2015), "Development and initial validation of a hospitality employees' job satisfaction index: Evidence from Australia”, International Journal of Contemporary Hospitality Management, 27(8), 1814-1838. Crossref

- Nadiri, H., \& Tanova, C. (2010), “An investigation of the role of justice in turnover intentions, job satisfaction, and organizational citizenship behavior in hospitality industry”, International Journal of Hospitality Management, 29(1), 33-41. Crossref

- Narangajavana, Y., Fiol, L. J. C., Tena, M. Á. M., Artola, R. M. R., \& García, J. S. (2017), "The influence of social media in creating expectations. An empirical study for a tourist destination”, Annals of Tourism Research, 65, 60 70. Crossref

- Pan, F. C. (2015), "Practical application of importance-performance analysis in determining critical job satisfaction factors of a tourist hotel", Tourism Management, 46, 84-91. Crossref

- Roberts, M. E., Stewart, B. M., \& Airoldi, E. M. (2016), “A Model of Text for Experimentation in the Social Sciences", Journal of the American Statistical Association, 111 (515), 988-1003. Crossref

- Sayaf, A.B. (2015), "Measuring Job Satisfaction Patterns in Saudi Arabia's Southern Regions Hospitals: Implications for Hospital Staff Retention”, International Journal of Management Science and Business Administration, 1(3), 29-49. Crossref

- Siahaan, E. (2017), “Can We Rely on Job Satisfaction to Reduce Job Stress?” International Journal of Management Science and Business Administration, 3(3), 17-26. Crossref

- Song, Z., Chon, K., Ding, G., \& Gu, C. (2015), "Impact of organizational socialization tactics on newcomer job satisfaction and engagement: Core self-evaluations as moderators", International Journal of Hospitality Management, 46, 180-18 Crossref

- Stater, K. J., \& Stater, M. (2019), "Is it "just work"? The impact of work rewards on job satisfaction and turnover intent in the nonprofit, for-profit, and public sectors", The American Review of Public Administration, 49(4), 495511. Crossref

- Symitsi, E., Stamolampros, P., \& Daskalakis, G. (2018), "Employees’ online reviews and equity prices”, Economics Letters, 162, 53-55. Crossref

- Tchinda, J.L.M. \& Bing, H.R. (2017), ”Job Satisfaction of Self-Employed Workers: Empirical Evidence from Cameroon Data", International Journal of Management Science and Business Administration, 3(6), 43-59. Crossref

- Tshivhase, T. \& Vilakazi, L. (2018), "Job Satisfaction: What factors in the Coal Mining Industry will lead to Higher Satisfaction?", International Journal of Management Science and Business Administration, 4(6), 17-25. Crossref

- Yang, J.-T., Wan, C.-S., \& Fu, Y.-J. (2012), “Qualitative examination of employee turnover and retention strategies in international tourist hotels in Taiwan", International Journal of Hospitality Management, 31(3), 837-848. Crossref

- Yeh, C. M. (2013), “Tourism involvement, work engagement and job satisfaction among frontline hotel employees”, Annals of Tourism Research, 42, 214-239. Crossref

- Zopiatis, A., Constanti, P., \& Theocharous, A. L. (2014), “Job involvement, commitment, satisfaction and turnover: Evidence from hotel employees in Cyprus", Tourism Management, 41, 129 Crossref 